\title{
An Agency Problem Analysis Of United States Vs. Microsoft
}

Steven Scott Stephens, (E-mail: sstephens@ut.edu), University of Tampa

\begin{abstract}
The Justice Department's antitrust case against Microsoft Corporation has generated considerable interest and passionate opinions, but in general is not well understood. This paper explains the legal basis and proceedings of the case in language accessible to the business community. At this writing, the appeals court has affirmed the trial court's conclusion that Microsoft violated the law in several respects, but has reversed the breakup remedy prescribed by the trial judge. Accordingly, this article examines, as a practical matter divorced from legal technicalities, whether there should be any further action taken at all, and if so, what the remedy should be. Interpreting the illegal conduct as symptoms of an agency problem leads to the conclusion that individual-based, rather than corporatebased, remedies would be more reasonable.
\end{abstract}

\section{Introduction}

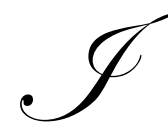

n United States v. Microsoft, ${ }^{1}$ the United States Court of Appeals unanimously upheld most of the trial judge's scathing findings of illegal conduct by officers and agents of the corporation. True, the part of the judgment breaking up the company was rejected, but the case was sent back to the district court for a new judge to fashion a different remedy for Microsoft's illegal conduct. A number of observers have suggested that the new remedy will include a substantial cash penalty, and that prospect raises the issue of agency costs.

It is well known that corporations can act only through agents, and that the objectives of agents may not coincide perfectly with those of their masters, who in the corporate context are the shareholders. This article argues that the agents of Microsoft who committed the acts found illegal by two federal courts could not have been acting in the interests of shareholders, given the blatantly illegal nature of their actions. It concludes that, since the case is marked by a substantial agency problem, any remedy that penalizes innocent stockholders (as a large cash penalty would) is wrong, and fails to establish adequate deterrent for the agents' illegal conduct. The remedy should focus on the individuals who performed the illegal acts, and penalize them personally, rather than diluting responsibility behind the corporate veil.

\section{Precursor Microsoft Litigation}

Looking at the history of Microsoft Corporation, it appears that a key element of its success has been conducting many of its transactions and decisions at the edges of the law, even to the extent of engaging in legally questionable conduct. At its inception, the company's founders represented to IBM that they had developed an operating system (AOS@) that would run an IBM Personal Computer (APC@), when in fact they had no such product. When the time came to deliver the OS, they had obtained one from its actual creator, who had called it QDOS $^{2}$ for Aquick and dirty OS. @ IBM suffered no damage from the misrepresentation so no actionable fraud occurred.

When Apple Computer developed the graphical, point-and-click user interface that made computing more accessible, Microsoft copied its "look and feel" and called its copy Windows. ${ }^{3}$ Apple sued, and Microsoft made subtle changes in its product to keep pace with Apple's claims in the lawsuit. Ultimately, since Microsoft was not proven to have copied any of the underlying programming code, and the screens produced by the two products were not quite identical,

Readers with comments or questions are encouraged to contact the author via email. 
the courts held there was no infringement on Apple's intellectual property.

During the years that followed, some observers ${ }^{4}$ contended that Microsoft's strategy to dominate all areas of software development was to copy the form and function of every existing type of profitable non-Microsoft program, daring the original programmer to bring a court action which it could not finance and therefore could not win. Instead of waiting for litigation, according ot his view, Microsoft would sometimes just commence marketing of the infringing product, simultaneously bringing a court action itself, to attack the other product's intellectual property status pre- emptively. According to this contention, Microsoft would then use cash generated by its OS monopoly to buy out the rights of the software at issue, at a price discounted due to the tendency of uncertain litigation. It would then exploit its internal knowledge of the operating system to make the program run more smoothly than outside programmers would be able to accomplish. There have also been claims that Microsoft deliberately made changes to new versions of DOS that would hobble software made by competitors, particularly Lotus $1-2-3 .^{5}$

The accusation that Microsoft used deliberate infringement and aggressive litigation as a systematic strategy to expand its reach is unproven, but the case of Stac Electronics is one instance in which precisely that sort of tactic was employed. ${ }^{6}$ Early in 1994, Microsoft was ordered to pay $\$ 120$ million after a jury found it infringed on Stac's patents for disk storage compression software. The verdict was more than three times Stac's sales for the previous fiscal year, but was barely $4 \%$ of Microsoft's revenues from the same period. Microsoft filed an appeal, and Stac, which by then was foundering and had few assets other than the lawsuit, agreed to settle the case. Microsoft obtained the right to use the Stac software, and agreed to pay Stac $\$ 1$ million per month royalties for 43 months. In addition, Microsoft agreed to buy $\$ 40$ million worth of Stac's outstanding stock.

Though it sounds like a lot of money, the settlement was hardly a victory for Stac; its stock price was depressed by the litigation and the royalties it was to receive for its only real product were $\$ 12$ million per year, far below the $\$ 37$ million in sales it had enjoyed before. Some shareholders sued Stac for allegedly failing to warn that Microsoft might drive them out of business, but the $9^{\text {th }}$ circuit U.S. Court of Appeals ruled that any reasonable investor should have anticipated that risk. ${ }^{7}$ The end result of the Stac suit was that Microsoft incorporated Stac's disk compression technology into its OS, and owned the right to do so for significantly less money than Stac had been making from the product before Microsoft's infringement began. More recently, Microsoft appears to have been planning litigation even as it negotiated a contract with Sun Microsystems for use of Sun's Java technology. Sun viewed the key to Java's success to be its "portability" B programs written in the Java language were able to run on any type of computer, using any operating system. In agreeing to let Microsoft develop and sell its own version of Java, Sun specifically bargained for Microsoft's promise to keep its version of Java "portable." Within days of signing the agreement, however, Microsoft released a Java version that was incompatible with Sun's, running only on computers using the Windows operating system. Sun sued, and the district court enjoined microsoft from using incompatible versions of Java. ${ }^{8}$ Microsoft appealed, and the ninth circuit U.S. court of appeals vacated the injunction, sending the case back to the district court. ${ }^{9}$ An injunction similar to the original was then entered by the district court. ${ }^{10}$ Microsoft's conduct in that case became evidence used in the most recent antitrust suit. ${ }^{11}$

\section{Microsoft's First Antitrust Case}

The first antitrust suit by the government against Microsoft emanated from an investigation initiated in 1990 by the Federal Trade Commission of the first Bush administration. ${ }^{12}$

Recent antitrust case arose primarily from Microsoft's tactics in gaining dominance over the market for web browsers- programs that retrieve files over the Internet and display them on the computer screen. There was, however, an earlier antitrust case against Microsoft which was resolved by a settlement agreement called a "consent decree."

The first Microsoft antitrust case centered on Microsoft's use of "per processor" contracts in selling computer manufacturers the right to use the Windows operating system. ${ }^{13}$ Under these contracts, Microsoft was to receive a Windows licensing fee for every computer sold by the manufacturer, whether it had Windows installed in it or not. A manufacturer who desired to sell computers with other operating system software in it, such as IBM's OS/2 or Digital Research 
DR-DOS, would thus need to pay twice for the operating system component of the computer once to the creator of the operating system installed in the computer, and again to Microsoft. Obviously, the effect of this arrangement was to make Windows computers less expensive than others, by inflating the price of the others. ${ }^{14}$ Microsoft also employed licensing contracts of remarkably long duration, which had minimum purchase requirements so large that most OEMs could not sell enough units to meet the minimum requirements, and according to the terms of the Microsoft-dictated license, an OEM could either pay for the unmet portion of the minimum requirement in cash, or enter into a new Agreement with Microsoft, adding the unmet minimum of the expiring contract to the minimum requirement of the new one.

The Federal Trade Commission deadlocked 2-2 and thus took no action against Microsoft; the Clinton Administration's Department of Justice entered into a settlement agreement or "consent decree" limiting the licensing practices that gave rise to the investigation. ${ }^{15}$ Microsoft also agreed not to participate in any tying arrangements, by which it required OEMs to purchase any other Microsoft product in order to buy DOS or Windows. ${ }^{16}$ When the consent decree was presented to the District Court for approval, Judge Sporkin rejected it:

The Government has declined to provide the Court any meaningful information concerning the substance of its investigation, i.e., what it investigated and the findings it made. Microsoft has gone a little further than the Government and tried to allay certain of the Court's concerns. However ... some of the assurances provided by Microsoft have proved to be unreliable and contrary to fact. ${ }^{17}$

The court held that the Tunney Act required information to be fully disclosed to the court before a consent decree could be approved, and cited pages of argument and testimony in which both the government and Microsoft refused to answer the court's concerns. ${ }^{18}$ In particular, the proposed decree failed to address in any way the initial accusation that Microsoft had engaged in a "vaporware" campaign against Borland's Turbo Basic software. A vaporware tactic entails announcing that the company will soon be releasing software with certain features and functions that are "better" than a competing software already on the market, in order to induce buyers to avoid buying the competing product in anticipation of the newer better release. This in itself is of course unobjectionable; but in this case Microsoft had no such product and allegedly had falsely announced one for the sole purpose of weakening competition. There was evidence, according to the trial judge, that this allegation was true, and that Microsoft's lawyers said the company intended to continue the practice. ${ }^{19}$ Just in case his language had not been strong enough, in the conclusion Judge Sporkin held:

It is clear to this Court that if it signs the decree presented to it, the message will be that Microsoft is so powerful that neither the market nor the Government is capable of dealing with all of its monopolistic practices. The attitude of Microsoft confirms these observations. ${ }^{20}$

Even while Microsoft was appealing Judge Sporkin's ruling and seeking to have the consent decree upheld, it was devising a strategy to use its monopoly in the OS market to gain a dominant position in the market for internet browsers. If the consent decree was not reinstated, Microsoft would not be bound by it, and it would be several years, if ever, before the government could successfully prosecute the case against it. But Microsoft wisely planned for the possibility that the decree would be reinstated by the appeals court, and designed its browser market strategy to defeat the antitying part of the agreement. The consent decree specified that it would "not be construed to prevent Microsoft from developing integrated products." ${ }^{21}$ Accordingly, the company began "integrating" its browser into the operating system.

The government had also appealed Judge Sporkin's denial of the consent decree, and the appeals court was convinced by the government's arguments. It held that the scope of the court's inquiry under the Tunney act was not to determine whether a consent decree is in the public interest, but whether it might be in the public interest whether it is "within the reaches of the public interest." 22

On appeal, Microsoft's tactic was to attack the Judge who had made the unfavorable ruling, asking that Judge Sporkin be disqualified for personal bias against [Microsoft].@ ${ }^{23}$ It also argued the lower court's focus on "vaporware" was misplaced, as it had originated from a book the judge read, rather than the actual complaints raised by the government. Despite the fact that the judge had relied on evidence submitted by one of the amici curiae in determining there was a legitimate issue regarding vaporware, the appeals court held that the judge appeared to base his findings on the 
book, and granted the relief Microsoft requested. The case was sent to a different judge, ${ }^{24}$ Thomas Penfield Jackson, who entered the consent decree on August 21, 1995. ${ }^{25}$

Less than two years later, the government sought to hold Microsoft in contempt of the consent decree for continuing to require OEMs to bundle its browser, Internet Explorer, with each copy of Windows 95 sold. Judge Jackson declined to hold the company in contempt, but did issue an injunction against bundling the browser with the OS pending a full hearing on the practice. ${ }^{26}$ The appeals court dissolved the injunction in a 2-1 decision, holding that Microsoft had at least facially demonstrated some benefit from the combining of its browser with Windows 95 , and thus could not be held in violation of the consent decree. ${ }^{27}$ The court did, however, expressly leave open the possibility that the company's conduct could be a violation of antitrust law, independently of the consent decree. ${ }^{28}$

\section{The Second Microsoft Antitrust Case}

The current Microsoft case was filed May 18, 1998, by the United States and twenty States. ${ }^{29}$ The defendant filed a motion arguing that even if the factual claims made by the government were true, they would form no legal basis for holding it liable, but the judge rejected that argument in a lengthy opinion on September 14, 1998. ${ }^{30}$ The district court held trial from October 19, 1998 to June 24, 1999, and the court issued over 330 pages of findings of fact on November $5^{\text {th }}$ of the same year. ${ }^{31}$

After the trial, the district court determined that the remainder of the case would be divided into three phases first, the court would issue findings of fact, then after the parties had a chance to comment on these, the court would write out the conclusions of law that follow from the facts. After yet another round of argument, the court would issue a final order containing addressing any remedy, if necessary.

In its extensive findings of fact, it was clear Microsoft had lost the trial even though the statement of conclusions of law were not to be issued for months. The trial court made plain that (1) it had taken the time to digest and understand all the technological issues in the case, and (2) regarded Microsoft's conduct of the trial as deceptive. At every point where there was a contradiction between testimony of a Microsoft witness and a government witness, the court discredited the Microsoft witness. A complete review of the findings of fact is beyond the scope of this article, which in the following paragraphs relates the findings considered important by the appeals court, which are the ones having legal significance. Suffice it at this point to observe that the district court found that Microsoft's highest- level executives, specifically Gates, Allchin and Kempin, acted at all times as if there were no federal antitrust laws, using the Windows monopoly without hesitation to advance other products that could not compete on the merits. Tellingly, the record contains many statements to this effect from these executives, revealing that they made no effort to conceal the trail of what amounts to a blatant violation of federal law, in the apparent expectation that the legal mechanism would never be applied to their conduct.

The trial judge, Thomas Penfield Jackson, could hardly be cast as a liberal activist. Coming from a business background, he was Reagan's first judicial appointment. His writings, on and off the bench, are sufficiently economically conservative and pro- business that one suspects the Microsoft attorneys were initially pleased when the case was assigned to him. And although Judge Jackson's official findings of fact were far less scathing than the media interviews the judge (inexplicably) gave, they were nevertheless much stronger than one normally sees in a civil case. From finding no. 412, the final one:

Most harmful of all is the message Microsoft's actions have conveyed to every enterprise with the potential to innovate in the computer industry. Through its conduct toward Netscape, IBM, Compaq, Intel, and others, Microsoft has demonstrated that it will use its prodigious market power and immense profits to harm any firm that insists on pursuing initiatives that could intensify competition against one of Microsoft's core products. Microsoft's past success in hurting such companies and stifling innovation deters investment in technologies and businesses that exhibit the potential to threaten Microsoft. The ultimate result is that some innovations that would truly benefit consumers never occur for the sole reason that they do not coincide with Microsoft's self-interest. 
Of course, the judge in the first Microsoft antitrust case had used even stronger language to condemn the company and cast it as a bully contemptuous of the law, but the company had successfully convinced the appeals court to overturn that ruling. When the conclusions of law and final order directing that Microsoft be split into two corporations was ultimately entered, the company naturally appealed. And when the appeals court heard arguments in the case, observers concluded a reversal was likely.

When the appeals court actually ruled, however, most of Judge Jackson's conclusions were upheld. The final order mandating that the company be split in two was vacated, and some of the grounds for liability found by Judge Jackson were disapproved, but none of the factual findings were reversed or discredited in any way by the appeals court. The district court held Microsoft violated federal law in many different ways, as seen in table 1, along with the appellate court's resolution of each offense. Of the four major categories of liability found by the trial court, only one was completely rejected by the appellate decision. One was sent back (remanded) to the trial court for reconsideration under a different standard, and two were upheld. More importantly, Judge Jackson had found that Microsoft committed eighteen separate acts or practices, any one of which would be a violation of the law. The appeals court eliminated six of these acts, and sent one back for further consideration, leaving a total of eleven separate violations of the law for which the company was to be held accountable.

What is most remarkable is not that the court rejected the bulk of Microsoft's protestations of innocence, and found it culpable for 11 separate acts or practices. It is the evident disdain for Microsoft's conduct of the litigation unmistakably expressed at a striking number of places in the unanimous opinion of the full (en banc) court.

For example, it is elementary antitrust law that a monopoly maintenance claim requires proof that the defendant is in fact a monopoly. Before Judge Jackson, Microsoft had made the amazing claim that it did not have monopoly power, and that likely formed part of the reason the judge found the company's executives to be without credibility. In the appeals court, Microsoft nevertheless claimed that it had no monopoly power, despite its $95 \%$ market share. The court made no effort to disguise its disdain for that argument, though it stopped short of explicitly terming it disingenuous. It affirmed the trial court's market definition, and hence its finding that the company held monopoly power. In subdued language that only a litigator would fully comprehend, the court ridiculed Microsoft's argument:

Microsoft's argument that Mac OS should have been included in the relevant market suffers from a flaw that infects many of the company's monopoly power claims: the company fails to challenge the District Court's factual findings, or to argue that these findings do not support the court's conclusions. ${ }^{32}$

Among appellate lawyers, it is well known that any challenge to a trial court's factual findings must be limited to an argument that there was insufficient evidence to support the findings. Arguments that the lower court misunderstood the evidence, or believed the wrong witness, are routinely rejected. Only a complete lack of any evidentiary support whatsoever will get an appellate court to reverse a trial judge's findings of fact. When there is any evidence at all supporting the factual findings, appellate lawyers all know that they must argue that the findings do not support the legal conclusions reached. In fact, making that determination is the primary role of the appellate court. Purporting to explain to lawyers representing one of the world's richest companies how the appellate process works is a deliberate, pointed rebuke to their work. But it does not end there:

This general, conclusory statement falls far short of what is required to challenge findings as clearly erroneous. [Citations omitted] Microsoft neither points to evidence contradicting the District Court's findings nor alleges that supporting record evidence is insufficient. And since Microsoft does not argue that even if we accept these findings, they do not support the District Court's conclusion, we have no basis for upsetting the court's decision to exclude Mac OS from the relevant market. ${ }^{33}$

It seems that Microsoft, having antagonized Judge Sporkin in the first antitrust case, and using Judge Sporkin's responses to the antagonism to attack him personally in attaining a reversal of his judgment learned that there was no penalty for antagonizing the court, and perhaps such behavior was even to be rewarded. As noted above, the text of Judge Jackson's Finding of Fact make it clear that the Judge was not only convinced the company violated the law, he was con- 
vinced they did not accidentally run afoul of obscure technicalities. Judge Jackson seemed convinced the company knew it was violating the law, because it believed the law lacked power over them. He also stated unequivocally that the company's executives were not believable, even when testifying under oath. Whether it was intentional or not, it seems evident the company antagonized Judge Jackson to nearly the degree it antagonized his predecessor. It does not, however, seemed to anticipate that its novel approach to appellate advocacy would antagonize the United States Court of Appeals, but apparently the court found Microsoft's opening argument insulting. It was, after all, Microsoft arguing it was not a monopoly, a claim that would insult the intelligence of just about anyone.

Despite the court's clear signal that it considered Microsoft's first argument to be insultingly lacking in the concerns properly addressed to the court, each subsequent argument was evaluated independently. Regarding the trial court's findings that its exclusionary practices such as threatening to withold Windows from computer manufacturers unless they agreed not to use the Netscape browser were illegal, Microsoft argued it was simply "exercising its rights as the holder of valid copyrights." ${ }^{34}$. The court did not find this argument persuasive either, concluding that it "borders on the frivolous." ${ }^{35}$ Expressing some frustration with the company's insistence on its "bold and incorrect position on the law" the court nevertheless carefully considered Microsoft's arguments and found merit in one of its defenses to three of the fourteen "exclusionary practices" the lower court had declared to be grounds for liability.

Yet, even in accepting Microsoft's argument on one point, the court reiterates its criticism of the others: "the only license restriction [of the four under consideration] Microsoft seriously defends as necessary to prevent a "substantial alteration' of its copyrighted work is the prohibition on OEMs automatically launching a substitute user interface"... ${ }^{36}$.

Where Microsoft cites its own executive's testimony for the proposition that "Our vision of deeper levels of technical integration is highly efficient and provides substantial benefits to customers and developers." the court wryly observes that the company "neither specifies nor substantiates those claims." ${ }^{37}$

For most of the remaining grounds of liability, the court simply observes that "Microsoft offers no justification..." "Other than protecting its monopoly." The necessity of offering procompetitive justification for a potentially anticompetitive practice is also well known among antitrust lawyers, but Microsoft made no effort to even try to make such an argument.

The court's level of frustration with Microsoft's arrogance was revealed once more in connection with the one count that contained an element of outright dishonesty on Microsoft's part. As noted a few pages ago, Microsoft entered into a contract with Sun, in which Microsoft obtained the rights to use Java in its browser. Microsoft specifically agreed to not create a version of Java that would damage its portability, and at the same time it was doing just that. But that dishonest behavior is not within the purview of the antitrust laws, which exist to protect competition, not competitors. What exposed Microsoft to antitrust liability for its dishonesty was continuing to claim its Java version was compatible and portable when it knows it was not, and indeed had specifically designed its version to "Kill cross-platform Java by growing the polluted Java market." ${ }^{38}$ As if it were seeking the understatement of the year award, the court simply observed, unsurprisingly, Microsoft offers no procompetitive explanation for its campaign to deceive developers. Id.

By the time the court addressed the remedies imposed by Judge Jackson, it had overtly or subtlety chastised Microsoft for making an essentially disingenuous argument no less than nine times. The court nevertheless concluded that the company should be entitled to a new hearing on the remedies issue, since some of the grounds for liability had been either eliminated or remanded by the appeals court. Moreover, although it found no evidence of actual bias in the trial court's rulings, it did order that the case be sent to a different judge when the remedies phase was reconsidered. At this writing, the case has been reassigned to a new judge, and any final order is months away.

\section{Agency costs}

When the manager of a corporation uses corporate assets and opportunities to advance personal goal at the ex- 
pense of the value of the firm, the manager is legally in violation of a fiduciary duty. ${ }^{39}$ If shareholders face a loss of either existing assets or valuable corporate opportunities, upon proof the loss results from a violation of fiduciary duty, they are entitled to collect damages from the offending officer by instituting a "derivative action."

Economically, however, the concept of "agency cost" is much broader than the legal conception of fiduciary duty. This is because there are a range of actions that generate agency costs, but would not, as a practical matter, ever give rise to liability for breach of fiduciary duty. One important reason is the business judgment rule, which protects corporate managers if their actions are a reasonably defensible exercise of business judgment. That rule is sensible, as without it the courts could be invoked to manage corporations - and even very wise judges are not in a position of comparative advantage in running companies. Accordingly, it is possible for managers to pursue some personal interests with corporate assets and opportunities, and within bounds there will be no legal consequence. Because this potential exists, corporate structure and procedures that minimize the potential for these agency costs tend to increase the value of the firm. Typical agency cost- containment mechanisms are (1) the threat of firing a manager; (2) the threat of a takeover; (3) expenditures on monitoring managers' actions and performance; and (4) incentive- based compensation. ${ }^{40}$ There are more esoteric agency-based arguments, such as Easterbrook's (1985) ${ }^{41}$ effort to explain the dividend puzzle as an effect of agency costs. In a variation on the monitoring approach (3) just mentioned, Easterbrook argues that companies pay dividends so that new and existing projects are financed via the capital markets rather than internally, exposing the company to the continuous scrutiny of the capital markets.

In the case of Microsoft, none of the agency-cost containment strategies usually employed are operative, except perhaps the incentive- based compensations. A few individuals who are the corporate managers hold blocks of stock so large they face no threat of firing; the same fact makes an outside takeover unthinkable. Microsoft pays no dividends and carries no long- term debt, ${ }^{42}$ minimizing the monitoring potential of the capital markets. On the other hand, Microsoft's managers all hold substantial positions in the company's stock, such that any actions that advance personal goals at the expense of shareholder wealth would cost the manager as well. At the margin, however, the costs of any such action would be borne only partially by even a very large blockholder, so that given a personal desire to perform a certain activity, it would cost the corporate officer less to do it through the corporation (costs shared among all the stockholders) than to do it personally. In the case of Microsoft, where the questionable acts appear to be gratuitous exercises of power for power's sake, the cost of exerting that kind of effect individually would be very high, since it is the corporation's monopoly power that makes the actions possible. It is hard to conceive even the wealth of the world's richest person being deployed in such a way as to hold power equivalent monopoly power over the PC industry worldwide. Accordingly, it is safe to conclude that none of the usual means of combating the agency problem are likely to be effective in the Microsoft case. Instead, minority shareholders are left to rely solely on the good faith and self- restraint of the managers themselves, and to legal protection afforded shareholders if the managers lack these virtues.

There has been a tremendous amount of academic commentary focused on the Microsoft antitrust case, ${ }^{43}$ but none have considered the agency implications of the managers' behavior. There are economists who portray Microsoft as an entrepreneur to be emulated, and similarly portray the government action as wrong- headed at best. But none of these acknowledge the existence of the deliberate campaign Microsoft used to "pollute" Java while lying to software developers about the compatibility between its Java and Sun's. And as both of the courts to look at the evidence on that issue have observed, Microsoft makes no denial that it embarked on the fraudulent scheme, and no serious attempt to defend it.

Given the breadth and complexity of the government's case, it is easy to lose sight of the fact that this one specific course of conduct is sufficient to warrant imposition of liability, and the company has made neither denial nor excuse. Moreover, even if it is true that prosecution of Microsoft is bad for the computer industry (Bittlingmayer and Mayer $2000)^{44}$ or for the economy generally (Leibowitz and Margolies 1999), ${ }^{45}$ it is sloppy analysis to conclude the inquiry there. It is necessary to balance the economic costs of antitrust law, if they are indeed implicated, with the broader costs that would stem from disintegration of the rule of law if certain individuals could, due to wealth or power, violate it with impunity. The unanimous opinion of the Unites States Court of Appeals for the District of Columbia Circuit resoundingly answered those who claim antitrust law, being outdated, should not give rise to action against Microsoft:

Even in those cases where forward looking remedies appear limited, the Government will continue to have an interest in defining the contours of the antitrust laws so that law abiding firms will have a clear sense of what is permissible and what is not. And the threat of private damage actions will remain to deter those firms inclined to test the limits of the 
law. ${ }^{46}$

\section{Conclusion}

Neither the conduct of the litigation nor the conduct that gave rise to the litigation is consistent with a group of company officers carrying out their fiduciary duty to maximize firm value. These are not the actions of ethical, competent corporate managers, but of insecure adolescents trying to prove their masculinity. These were corporate managers running the wealthiest company in the world, with access to the best legal talent. The actions they took were so obviously illegal that it is impossible they did not know that at the time, unless they deliberately cultivated and preserved that ignorance.

The first time these managers were faced with the possibility of accountability for their illegal conduct, they reached a sudden and unexplained "settlement" with the government. The trial judge was outraged that the capitulation by the government was presented to him as a settlement. By fashioning a personal attack on the integrity of the trial judge, Microsoft escaped any legal consequences.

Emboldened by its legal successes, Microsoft's managers undertook to use the monopoly power they possessed from the popularity of Windows to crush Netscape in the browser market. This is hard to justify in terms of legitimate shareholder wealth Microsoft was giving its browser away for free, and its leaders had said it would continue to do so. Unless the leaders were lying, it is hard to see how gaining market share for a free product maximizes shareholder wealth. But it is easy to see why it is illegal; again, it could not be a simple mistake or unexpected technicality.

Any doubt that Gates, Allchin, Ballmer and Kempin were innocent victims of an overly complex set of antitrust laws is dispelled by the abject dishonesty involved in representing to software developers that the MS version of Java was truly Java compatible when they had specifically engineered it to "pollute" Java. First, this establishes that the Microsoft apologists who try to cast the case as improper are in the unenviable position of defending dishonest conduct of business. Second, it renders unassailable the claim that the action was taken for personal reasons and not for the interests of shareholders.

Whether one believes the antitrust laws are right or wrong, anyone who has not confused himself with a deity can recognize that one's beliefs about what the law should be do not define what the law is. And as the attempts to defend Microsoft's conduct under the law have offended (so far) two of the judges on the district court and all of the judges on the circuit (appellate) court, one must begin questioning the Microsoft managers' claim that they are victims of wealth envy. The picture that unfolded in court is of corporate managers who do not believe the law can touch them, who consider themselves all-powerful. Indulging in this hubristic delusion is at the expense of, not in the interest of shareholders.

Accordingly, the Microsoft antitrust case is really an agency problem. The corporate managers, desperate to maintain their own self- images of supremacy, have taken increasingly reckless actions toward their personal ends. It is a classic case of the inability of minority stockholders to protect themselves from the desire of managers to use the corporate assets for personal purposes. As such, it appears improper to impose a "remedy" that punishes the innocent minority shareholders. The illegal actions of Gates and his inner circle do not appear to have generated any additional revenues for the corporation, only feelings of power so desperately needed by the managers personally. Punishing the entire company for actions which benefited only a few managers would be compounding the abuse.

The question remains what remedy is appropriate. It may be that the divestiture order is the best choice, if that would cause the sum of the stock prices of the disaggregated entities to rise. In fact, if the hypothesis of this article is true, and the shareholders are better off without managers who cannot resist the temptation to use monopoly power illegally, then the company's value would be greater in parts than in whole.

Another possible remedy that does not directly penalize shareholders would be a change in management. If Gates, Allchin, Kempin, and Ballmer were permanently barred from exercising any influence on the company at all, that should (if this hypothesis is correct) cause a rise in the company's stock price. To those who worry that it would let the violations of law go largely unpunished, the response is to note that the possibility of a class-action shareholder derivative 
action, seeking to recover from the personal assets of the deposed officers, would be one way to accomplish that if it is appropriate.

Table 1

Panel 1. Violations of Federal Law by Microsoft as found by the trial court (first three columns and the appeals court fourth column). "Affirmed" means the finding that Microsoft broke the law stands; "Eliminated" means that conduct by the company was held not to be illegal.

\begin{tabular}{|c|c|c|c|}
\hline $\begin{array}{l}\text { Law Ostensibly } \\
\text { Violated }\end{array}$ & Type of Conduct & Specific Conduct & Result on Appeal \\
\hline \multirow{9}{*}{$\begin{array}{l}\text { Sherman Act sec. } \\
\text { 2- Exclusionary } \\
\text { Practices and } \\
\text { Monopoly Main- } \\
\text { tenance }\end{array}$} & \multirow{3}{*}{$\begin{array}{l}\text { Integrating IE into } \\
\text { Windows }\end{array}$} & $\begin{array}{l}\text { Excluding IE from the Add/Remove } \\
\text { Programs menu }\end{array}$ & $\begin{array}{l}\text { Affirmed. MS "offers no justification..." } \\
\text { "Other than protecting its monopoly." }\end{array}$ \\
\hline & & $\begin{array}{l}\text { Commingling IE -specific code with } \\
\text { Windows code in DLLs (library files } \\
\text { containing functions called by pro- } \\
\text { grams) }\end{array}$ & $\begin{array}{l}\text { Affirmed. MS "offers no justification..." } \\
\text { "Other than protecting its monopoly." }\end{array}$ \\
\hline & & $\begin{array}{l}\text { Overriding the user's choice of any } \\
\text { browser other than IE in some cir- } \\
\text { cumstances, even if the user has taken } \\
\text { steps to make a different program the } \\
\text { default browser }\end{array}$ & $\begin{array}{l}\text { Eliminated. The user's choice of default } \\
\text { browser is only overridden by actions that } \\
\text { invoke other Microsoft programs, such as } \\
\text { the MS help system. }\end{array}$ \\
\hline & \multirow{3}{*}{$\begin{array}{l}\text { Exclusionary con- } \\
\text { tracts with com- } \\
\text { puter manufactur- } \\
\text { ers (OEMs) }\end{array}$} & $\begin{array}{l}\text { Prohibiting OEMs from removing } \\
\text { any icons, folders or menu entries, } \\
\text { thus requiring that IE be readily } \\
\text { available on every new computer } \\
\text { shipped }\end{array}$ & $\begin{array}{l}\text { Affirmed. Microsoft's defense "borders on } \\
\text { the frivolous." }\end{array}$ \\
\hline & & $\begin{array}{l}\text { Prohibiting OEMs from altering the } \\
\text { "initial boot sequence" that gives } \\
\text { prominence to Internet Service Pro- } \\
\text { viders who use IE, and excludes ISVs } \\
\text { that use Netscape }\end{array}$ & $\begin{array}{l}\text { Affirmed, except MS should face no liabili- } \\
\text { ty for prohibiting an alteration that prevents } \\
\text { the Windows desktop from ever being seen } \\
\text { by the user. The other restrictions do sup- } \\
\text { port liability. }\end{array}$ \\
\hline & & $\begin{array}{l}\text { Prohibiting any alteration of the } \\
\text { Windows Desktop }\end{array}$ & $\begin{array}{l}\text { Affirmed. Microsoft's defense "borders on } \\
\text { the frivolous." }\end{array}$ \\
\hline & \multirow{3}{*}{$\begin{array}{l}\text { Exclusionary Con- } \\
\text { tracts with Internet } \\
\text { Access Providers }\end{array}$} & $\begin{array}{l}\text { Offering IE, and an IE development } \\
\text { kit, at no charge. }\end{array}$ & $\begin{array}{l}\text { Eliminated. In the absence of a claim of } \\
\text { predatory pricing, low prices do not give } \\
\text { rise to liability. }\end{array}$ \\
\hline & & $\begin{array}{l}\text { Paying a "bounty" to the IAP for each } \\
\text { customer who signed up using IE }\end{array}$ & $\begin{array}{l}\text { Not specifically addressed; apparently with- } \\
\text { in the scope of the ruling above. }\end{array}$ \\
\hline & & $\begin{array}{l}\text { Featuring an IAP on the Windows } \\
\text { desktop in exchange for the IAP's } \\
\text { agreement to keep Netscape usage } \\
\text { among its customers below } 25 \%\end{array}$ & Affirmed. No justification. \\
\hline
\end{tabular}

Panel 2. Violations of Federal Law by Microsoft as found by the trial court (first three columns and the appeals court fourth column). "Affirmed" means the finding that Microsoft broke the law stands; "Eliminated" means that conduct by the company was held not to be illegal 


\begin{tabular}{|c|c|c|c|}
\hline $\begin{array}{c}\text { Law Ostensibly } \\
\text { Violated }\end{array}$ & Type of Conduct & Specific Conduct & Result on Appeal \\
\hline \multirow{6}{*}{$\begin{array}{l}\text { Sherman Act sec. } \\
\text { 2- Exclusionary } \\
\text { Practices and } \\
\text { Monopoly Main- } \\
\text { tenance (cont'd) }\end{array}$} & \multirow{2}{*}{$\begin{array}{l}\text { Exclusionary Con- } \\
\text { tracts with other } \\
\text { Software and } \\
\text { hardware vendors }\end{array}$} & $\begin{array}{l}\text { Preferential access to Windows } \\
\text { code and APIs for developers } \\
\text { who agree to make IE the de- } \\
\text { fault browser called by their ap- } \\
\text { plications }\end{array}$ & Affirmed. No justification. \\
\hline & & $\begin{array}{l}\text { Continuing to make Office for } \\
\text { Mac only if Apple agreed to stop } \\
\text { using Netscape }\end{array}$ & Affirmed. "No procompetitive justification." \\
\hline & \multirow{4}{*}{$\begin{array}{l}\text { Efforts to Subvert } \\
\text { Java }\end{array}$} & $\begin{array}{l}\text { Release of Java "virtual machine" } \\
\text { incompatible with Sun's. }\end{array}$ & $\begin{array}{l}\text { Eliminated. Incompatibility not itself a ground } \\
\text { for liability; liability imposed only for exclusio- } \\
\text { nary contracts or deception (see below) }\end{array}$ \\
\hline & & $\begin{array}{l}\text { Contracts with software devel- } \\
\text { opers gave them access to Win- } \\
\text { dows code and specifications } \\
\text { only if they agreed to use IE, } \\
\text { hence Microsoft's incompatible } \\
\text { Java Virtual Machine. }\end{array}$ & Affirmed. "No procompetitive justification." \\
\hline & & $\begin{array}{l}\text { Deception of software develop- } \\
\text { ers by publicly entering into } \\
\text { contract with Sun to produce } \\
\text { only a Sun-compatible JVM, } \\
\text { while actually producing a deli- } \\
\text { berately incompatible one. }\end{array}$ & $\begin{array}{l}\text { Affirmed. No doubt that the deception occurred. } \\
\text { "No procompetitive justification." }\end{array}$ \\
\hline & & $\begin{array}{l}\text { Threatening Intel with retaliation } \\
\text { in other markets if it continued to } \\
\text { develop a JVM that would run in } \\
\text { the absence of Windows }\end{array}$ & $\begin{array}{l}\text { Affirmed. "Microsoft lamely characterizes its } \\
\text { threat to Intel as 'advice.'" P. } 77 \text {. }\end{array}$ \\
\hline
\end{tabular}

Panel 3. Violations of Federal Law by Microsoft as found by the trial court (first three columns and the appeals court fourth column). "Affirmed" means the finding that Microsoft broke the law stands; "Eliminated" means that conduct by the company was held not to be illegal. 


\begin{tabular}{|l|l|l|l|}
\hline $\begin{array}{l}\text { Law Ostensibly } \\
\text { Violated }\end{array}$ & Type of Conduct & \multicolumn{1}{c|}{ Specific Conduct } & \multicolumn{1}{c|}{ Result on Appeal } \\
\hline $\begin{array}{l}\text { Sherman Act sec. } \\
\text { Practices and } \\
\text { Monopoly Main- } \\
\text { tenance }\end{array}$ & $\begin{array}{l}\text { Course of Conduct } \\
\text { as a Whole }\end{array}$ & $\begin{array}{l}\text { Actions described above, taken } \\
\text { together, constitute illegal course } \\
\text { of conduct. }\end{array}$ & $\begin{array}{l}\text { Eliminated. Course of Conduct liability applies } \\
\text { only when the underlying acts are insufficient in } \\
\text { themselves to give rise to liability, and here the } \\
\text { individual acts were sufficient to impose liabili- } \\
\text { ty. }\end{array}$ \\
\hline $\begin{array}{l}\text { Sherman Act sec. } \\
\text { 2- Attempted } \\
\text { Monopolization }\end{array}$ & $\begin{array}{l}\text { Attempt to mono- } \\
\text { polize the browser } \\
\text { market }\end{array}$ & $\begin{array}{l}\text { Same actions as described in re- } \\
\text { gard to exclusionary contracts } \\
\text { and monopoly maintenance } \\
\text { counts }\end{array}$ & $\begin{array}{l}\text { Eliminated. District court mistakenly applied } \\
\text { same analysis to attempted monopolization that } \\
\text { it applied to monopoly maintenance counts; un- } \\
\text { der correct standard, the government's evidence } \\
\text { fails to establish attempted monopolization in } \\
\text { the browser market. 83-84. }\end{array}$ \\
\hline $\begin{array}{l}\text { Sherman Act sec. } \\
\text { 1-Tying }\end{array}$ & $\begin{array}{l}\text { Conditioning sale } \\
\text { of one product on } \\
\text { the purchase of a } \\
\text { second, separate } \\
\text { product. }\end{array}$ & $\begin{array}{l}\text { Refusing to sell Windows except } \\
\text { in conjunction with IE }\end{array}$ & $\begin{array}{l}\text { Sent back for reconsideration. The trial court } \\
\text { applied a per se illegality standard, when it } \\
\text { should have applied a reasonableness standard } \\
\text { instead. 89-90. }\end{array}$ \\
\hline
\end{tabular}

\section{Notes and References}

${ }^{1} 253$ F.3d 34 (D.C.Cir. 2001).

${ }^{2}$ Akemann, Microsoft's Licensing Agreements: Theory and Evidence on the Sale of MS-DOS and Windows, 24 Iowa J. Corp. L. 553, 558 (1999)

${ }^{3}$ Terry Nicolas P., GUI Wars: The Windows Litigation and the Continuing Decline of Look and Feel, 47 Ark. L. Rev. 93 (1994)

${ }^{4}$ Cooper, Antitrust as Consumer Protection in the New Economy: Lessons from the Microsoft Case 52 Hastings L.J. 813 (2001) See also James Wallace \& Jim Erickson, Hard Drive: Bill Gates and the Making of the Microsoft Empire (1992).

${ }^{5} I d$. It seems unlikely proof of this allegation exists, however, as if it did, it would form the basis for a class- action fraud suit by all purchasers of the product that contained a deliberate, secret defect while being sold as the general purpose, standard operating system.

${ }^{6}$ Stac Electronics Inc. v. Microsoft Corp., No. 93-0413 (C.D. Cal. February 23, 1994). See also, Current Developments, Proprietary Rights, 11(4) Computer Lawyer 29 (1994); Whit, Michael, Microsoft Must Pay \$120 Million, Legal Intelligencer, February 25, 1994 p.11

${ }^{7}$ In Re Stac Electronics Securities Litigation, 89 F. 3d 1399 (9 ${ }^{\text {th }}$ Cir. 1996).

${ }^{8}$ Sun Microsystems, Inc. v. Microsoft Corp., 21 F. Supp. 2d 1109, 1126 (N.D. Cal. 1998)

${ }^{9}$ Sun Microsystems, Inc. v. Microsoft Corp., 188 F.3d 1115, 1121 (9th Cir. 1999)

${ }^{10}$ Sun Microsystems, Inc. v. Microsoft Corp., 87 F. Supp. 2 d 992 (ND Cal 2000)

${ }^{11}$ United States v. Microsoft, 253 F.3d 34, 74 (D.C.Cir. 2001).

${ }^{12}$ Gilbert, R. and Katz, M., An Economist ' s Guide to U.S. v. Microsoft, 15(2) Journal of Economic Perspectives 25, 
$26(2001)$.

${ }^{13}$ According to the trial court, the government 's complaint also accused: (1) that Microsoft gave its developers of applications software information about its operating systems software before providing it to other applications developers; (2) that Microsoft announced that it was developing a non-existent version of operating software to dissuade Original Equipment Manufacturers ("OEMs") from leasing a competitor's operating system; [and] (3) that Microsoft required OEMs that licensed its operating system software also to license Microsoft applications. United States v. Microsoft, 159 F.R.D. 318 (D.D.C. 1995)

${ }^{14}$ Akmann, supra note 2, argues that this effect is trivial as a practical matter, as other contractual provisions requiring very long terms and large minimum purchases empirically dominate the Aper processor@ license metering. Oddly, however, Akmann does not present the data necessary to support such a claim.

${ }^{15}$ United States v. Microsoft, 159 F.R.D. 318, 324 (D.D.C. 1995).

${ }^{16}$ Gilbert and Katz, supra note 12 at 26.

${ }^{17}$ United States v. Microsoft, 159 F.R.D. 318, 327 (D.D.C. 1995).

${ }^{18} I d$. at $331-37$

${ }^{19}$ Id at $335-36$.

This Court cannot ignore the obvious. Here is the dominant firm in the software industry admitting it "preannounces" products to freeze the current software market and thereby defeat the marketing plans of competitors that have products ready for market. Microsoft admits that the preannouncement is solely for the purpose of having an adverse impact on a competitor's product. Its counsel states it has advised its client that the practice is perfectly legal and it may continue the practice. This practice of an alleged monopolist would seem to contribute to the acquisition, maintenance, or exercise of market share.

${ }^{20} I d$ at 337. The court also noted several acts of deceitful conduct by the company. Id.

${ }^{21}$ Gilbert and Katz, supra note 12 at 26.

${ }^{22}$ United States v. Microsoft, 56 F. 3d 1448, 1460 (D.C. Cir. 1995)

${ }^{23}$ United States v. Microsoft, 56 F. 3d 1448, 1455 (D.C. Cir. 1995)

${ }^{24} I d$ at $1463-65$.

${ }^{25}$ The full text of the agreement is located at United States v. Microsoft, 1995-2 Trade Cases (CCH) P71,096 (D.D.C. 1995).

${ }^{26}$ United States v. Microsoft, 980 F. Supp. 537 (D.D.C. 1997).

${ }^{27}$ United States v. Microsoft 147 F. 3d 935, 950 (D.C.Cir. 1998).

${ }^{28} I d$ at 955 n. 14.

${ }^{29}$ United States v. Microsoft, 1998-2 Trade Cases (CCH) P.72, 261 (order denying Microsoft ' s Motion for Summary Judgment, September 14, 1998) 
${ }^{30} I d$.

${ }^{31}$ United States v. Microsoft, 84 F. Supp. 2 d 9 (D. D.C. 1999)

${ }^{32} 253$ F. 3d at 52

${ }^{33} I d$.

${ }^{34}$ Id. at 62

${ }^{35}$ Id at .63

${ }^{36}$ Id at 63

${ }^{37}$ Id at. 66.

${ }^{38}$ Id at. 77.

${ }^{39}$ Corporate managers owe fiduciary duties to their shareholders. Dodge v. Ford Motor Co., 170 N.W. 668 (Mich 1919). The nature of the fiduciary duty is a strict requirement to place the corporate interests above the individual's, employing the "punctilio of an honor most sensitive." Meinhard v. Salmon, 164 N.E. 545, 546 (N.Y. 1928). Whether this duty is followed in practice is questioned by Smith, The Shareholder Primacy Norm, 23 Iowa Journal of Corporate Law 277 (1998).

40 Michael C. Jensen \& William H. Meckling, Theory of the Firm: Managerial Behavior, Agency Costs and Ownership Structure, 3 J. Fin. Econ. 305 (1976).

${ }^{41}$ Easterbrook, Two Agency-Cost Explanations of Dividends, 74 Am. Econ. Rev. 650 (1984)

${ }^{42}$ Microsoft Quarterly Report 10-Q, May 15, 2001

${ }^{43}$ See, Symposium on the Microsoft Case, 15 Journals of Economic Perspectives 25-80 (2001). The three articles that constitute the symposium are written by Richard Gilbert and Michael Katz, who were consulted by the government in connection with the litigation, Benjamin Klein, who has been a Microsoft consultant, and Michael Whinston, who is involved only as an academinc observer.

${ }^{44}$ George Bittlingmayer \& Thomas W. Hazlett, DOS Kapital: Has Antitrust Action against Microsoft Created Value in the Computer Industry? 55 J. Fin. Econ. 329 (2000). The article set up the false premise that a "good" antitrust case should cause the value of competitiors' stock to rise, and since this one did not, it should be likened to a communist/ Marxist government action. Had the authors acknowledged the contagion literature the argument would have been different? In a more recent article, Bittlingmayer dismissed the federal judge's findings of fact: "I disagee." Bittlingmayer, U.S. v. Microsoft, cui Bono? 9 Cornell J. Law \& Public Policy 9 (1999) Of course the United States Court of Appeals (subsequently) agreed with Judge Jackson, not Professor Bittlingmayer.

45 Liebowitz and Margolies, Winners, Losers and Microsoft (1999)

${ }^{46} 253$ F. 3d at 49.

Notes 
